Int. J. Dev. Biol. 56: 173-182

doi: $10.1387 / \mathrm{ijdb} .113439$ ts

\title{
The planarian P2X homolog in the regulation of asexual reproduction
}

\author{
TOSHIHIDE SAKURAI ${ }^{1}$, HAYOUNG LEE ${ }^{1}$, MAKOTO KASHIMA ${ }^{1}$, YUMI SAITO ${ }^{1}$, TETSUTARO HAYASHI ${ }^{2}$, \\ TOMOMI KUDOME-TAKAMATSU ${ }^{2}$, OSAMU NISHIMURA ${ }^{3}$, KIYOKAZU AGATA ${ }^{1}$ and NORITO SHIBATA*,3 \\ ${ }^{1}$ Dept. Biophysics, Grad. School of Science, Kyoto Univ. ${ }^{2}$ Center for Dev. Biol., Riken and \\ ${ }^{3}$ Global COE Program. Evolution and Biodiversity, Grad. School of Science, Kyoto Univ. Kyoto, Japan
}

\begin{abstract}
The growth in size of freshwater planarians in response to nutrient intake is limited by the eventual separation of tail and body fragments in a process called fission. The resulting tail fragment regenerates the entire body as an artificially amputated tail fragment would do, and the body fragment regenerates a tail, resulting in two whole planarians. This regenerative ability is supported by pluripotent somatic stem cells, called neoblasts, which are distributed throughout almost the entire body of the planarian. Neoblasts are the only planarian cells with the ability to continuously proliferate and give rise to all types of cells during regeneration, asexual reproduction, homeostasis, and growth. In order to investigate the molecular characteristics of neoblasts, we conducted an extensive search for neoblast-specific genes using the High Coverage Expression Profiling (HiCEP) method, and tested the function of the resulting candidates by RNAi. Disruption of the expression of one candidate gene, DjP2X-A (Dugesia japonica membrane protein P2X homologue), resulted in a unique phenotype. DjP2X-A RNAi leads to an increase of fission events upon feeding. We confirmed by immunohistochemistry that DjP2X-A is a membrane protein, and elucidated its role in regulating neoblast proliferation, thereby explaining its unique phenotype. We found that DjP2X-A decreases the burst of neoblast proliferation that normally occurs after feeding. We also found that DjP2X-A is required for normal proliferation in starved animals. We propose that DjP2X-A modulates stem cell proliferation in response to the nutritional condition.
\end{abstract}

KEY WORDS: planarian, fission, P2X, pluripotent stem cell

\section{Introduction}

Reproduction is a fundamental feature of the survival of an organism. Germ cell-mediated sexual reproduction is commonly employed among multicellular animals. However, asexual reproduction mediated by somatic multi- or pluripotent stem cells is also observed in many invertebrate species (Agata et al., 2006). Although the regulation of sexual reproduction via germ cells has been well studied, our understanding of the cellular and molecular mechanisms underlying asexual reproduction in multicellular organisms remains unclear.

The freshwater planarian Dugesia japonica possesses robust regenerative ability that allows for regeneration of a complete functional individual from almost any fragment produced by artificial amputation. $D$. japonica's regenerative capabilities are employed during asexual reproduction under natural conditions.
Planarians can grow or de-grow in response to nutrient uptake, while maintaining their normal body proportions, by modulating the number of cells composing their bodies (Baguñá and Romeo, 1981; Oviedo et al., 2003; Takeda et al., 2009). Upon feeding, asexual $D$. japonica propagates by spontaneously dividing its body into two fragments posterior to the pharynx in a process called "fission" (Agata et al., 2006; Takeda et al., 2009). Both fragments regenerate and develop into complete functional planarians via a process like that which occurs after artificial amputation, and thus planarians propagate asexually.

In some invertebrates, such as hydra, colonial tunicates, and planarians, it has been proposed that the somatic stem cell system

Abbreviations used in this paper: DjP2X-A, Dugesiajaponica P2X homologue;HiCEP, high
coverage expression profiling; $\mathrm{P} 2 \mathrm{X}$, type 2 , subtype X ionotropic purinergic receptor.

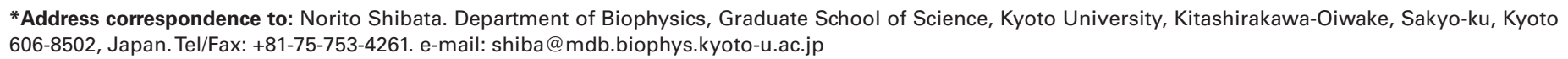

Supplementary Material (one figure) for this paper is available at: http://dx.doi.org/10.1387/ijdb.113439ts

Final, author-corrected PDF published online: 16 March 2012

ISSN: Online 1696-3547, Print 0214-6282

(C) 2012 UBC Press

Printed in Spain 
has an important role in the asexual reproduction (Agata et al., 2006). Among these animals, planarians have been best studied at the cellular and molecular level regarding the relationship between somatic stem cells and artificial regeneration (Agata et al., 2006; Reddien et al., 2005; Shibata et al., 2010). Planarian somatic stem cells, called "neoblasts", are unique among planarian cells in that they are able to proliferate and show sensitivity to X-and gamma-ray irradiation (rev. in Shibata et al., 2010). Neoblasts also show pluripotency, meaning that they can give rise to all types of cells, including germline cells. When planarians are irradiated with $\mathrm{X}$ - or gamma-rays, the neoblasts are specifically eliminated and consequently of the animals lose regenerative ability (Wolff and Dubois, 1948). Transplantation of a single neoblast can restore the regeneration in irradiated planarians, demonstrating both the pluripotency of neoblasts and their indispensability for planarian regeneration (Wagner et al., 2011). Recently, a requirement for JNK (c-Jun N-terminal kinase) signaling in the cell cycle progression of the neoblasts in D. japonica was reported (Tasaki et al., 2011). Prevention of cell proliferation by U600125, a JNK inhibitor, blocks regeneration, indicating that proper cell proliferation of the neoblasts is necessary for regenerative ability.

Recent efforts of planarian researchers have unveiled a part of the molecular signature of the neoblasts and the function of different components of this "signature". Notably, it has been reported that many genes encoding for RNA-binding proteins, for example piwi/ago family genes, and genes related to DNA replication, such as pcna or MCM (Proliferating cell nuclear antigen and Minichromosome maintenance, respectively) genes, are expressed and function in the neoblasts of $D$. japonica (reviewed by Shibata et al., 2010; Rouhana etal., 2010). RNA interference (RNAi) experiments have revealed that some of the RNA-binding protein genes are involved in neoblast maintenance, proliferation or differentiation, and knockdown of these genes' expression results in regenerative defects (Rouhana et al., 2010). Although the proper functioning of neoblasts is important for planarian regenerative ability, we still do not know the relationship between the neoblasts and fission, or the molecular mechanism of fission.

Comprehensive gene expression analyses provide abundant information about the molecular signature of cells or tissues. In order to define "stemness" in terms of the molecular signature of the neoblasts, we carried out comprehensive gene expression analysis in $D$. japonica by the HiCEP (High Coverage Expression Profiling) method (Shibata et al., 2012). HiCEP is a method of gene expression analysis based on AFLP (amplified length polymorphism) that enables us to detect and compare genome-wide gene expression between different experimental samples (Fukumura et al., 2003). Using HiCEP, we compared gene expression among intact planarians, X-ray-irradiated planarians, and a neoblast-

Fig. 1. Distribution pattern of DjP2X-A mRNA expressing cells in intact and regenerating planarians. (A) Expression of DjP2X-A mRNA in an intact animal detected by whole-mount in situ hybridization. Cells expressing DjP2X-A were observed throughout the body except in the head region. (B) Expression of DjP2X-A in X-ray-irradiated planarians. The expression completely disappeared. Expression of DjP2X-A in regenerating planarians at (C) 12 hr, (D) 1 day, (E) 2 days, (F) 3 days, (G) 4 days and (H) 5 days after amputation. Scale bar: $500 \mu \mathrm{m}$. enriched fraction collected by FACS (fluorescence activated cell sorting), and thereby found 42 genes that are specifically expressed in X-ray-sensitive cells, mainly the neoblasts (Shibata et al., 2012). Among them, we found that a $P 2 X$ homolog, named $D j P 2 X-A$, is expressed in the neoblasts. $P 2 X$ is a family of $P 2$ receptors that bind extracellular ATP, resulting in increased cation conductance for many kinds of ions (Roberts et al., 2006). In vertebrates, it is known that P2X is widely functional throughout the body, including in neural cells and stem cells. It regulates a great variety of cellular functions, such as cell growth, apoptosis, cytokine release, cell proliferation and the development of cancer (Roberts et al., 2006).

Here, we report that continued feeding of $D j P 2 X-A$ doublestranded RNA (dsRNA) increased the fission frequency to about three fold-higher than that of control animals. We also found that DjP2X-A is a membrane protein involved in slowing down of the rate of proliferation of the neoblasts after feeding. Finally, we found that DjP2X-A is required for normal cell proliferation under poor nutrient conditions. From these results, we propose that DjP2X-A modulates neoblast proliferation in response to nutritional status, and that increased neoblast proliferation is one of the causes of fission.

\section{Results}

\section{DjP2X-A encodes a neoblast-specific protein in planarians}

$D j P 2 X-A$ was identified as a neoblast-specific gene through comprehensive gene expression analysis as described above (Methods; Shibata et al., 2012). Whole-mount in situ hybridization analysis showed that this gene is expressed in a typical neoblast-specific expression pattern in intact animals, in which cells expressing $D j P 2 X-A$ were observed throughout the body in the mesenchymal space posterior to the eyes (Fig.1A). DjP2X-A expression was not detected in animals depleted of neoblasts by $X$-ray irradiation (Fig. 1B), indicating that $D j P 2 X-A$ is specifically expressed in the neoblasts. During regeneration, $D j P 2 X-A$-positive cells were not observed in the blastema region, indicating that $D j P 2 X-A$ was expressed exclusively in undifferentiated neoblasts, and was not expressed in their differentiating progeny located in the blastema (Fig. $1 \mathrm{C}-\mathrm{H}$ ). Faint expression of $D j P 2 X-A$ was detected in the post-blastema region, where actively proliferating neoblasts are accumulated early in regeneration (Fig. 1 D,E).
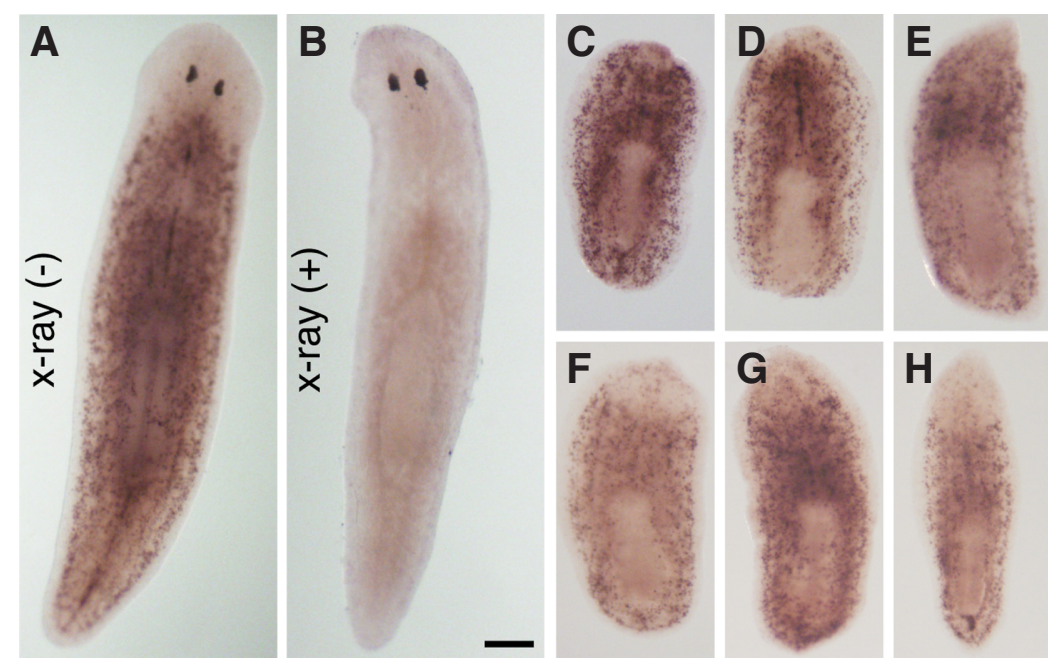

H 

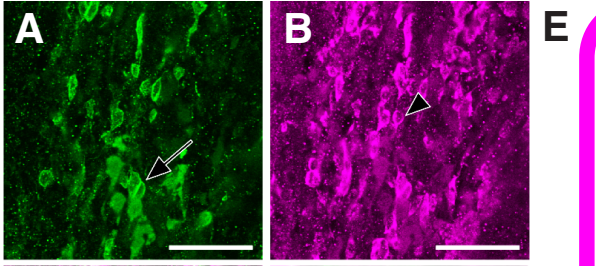

$\operatorname{PiwiA}(+)$ $100 \%(n=4)$
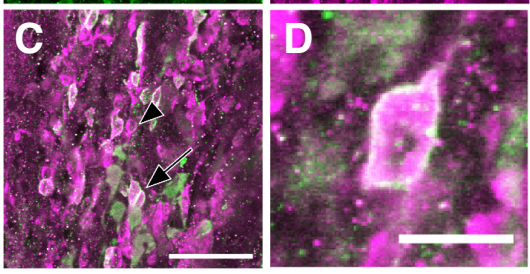

$\mathrm{P} 2 \mathrm{X}-\mathrm{A}(+)$

$48.3 \pm 3.3 \%$
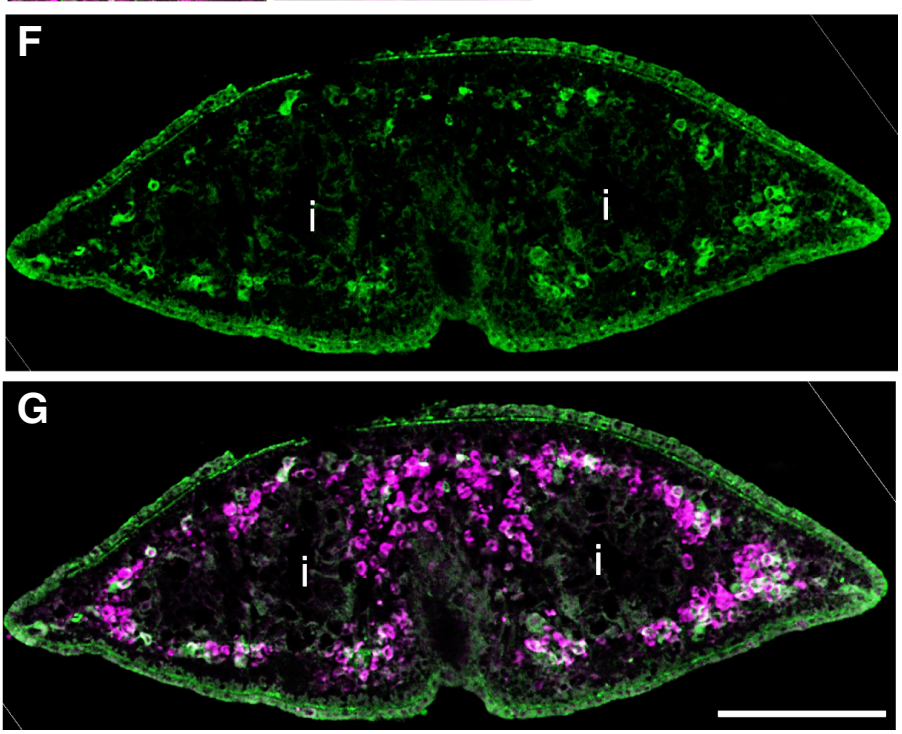

Fig. 2. Detailed observation of DjP2X-A protein-positive cells. (A) Cells stained with anti-DjP2X-A antibody. (B) Cells stained with anti-DjPiwiA antibody. (C) Merged view of (A) and (B). Arrow indicates DjP2X-A DjPiwiA-double-positive cell, and arrowhead indicates DjPiwiA-positive/ DjP2X-A-negative cell. Scale bar: 50 um. (D) Higher magnification of DjP2XA/DjPiwiA-double-positive cell. DjP2X-A was localized on the cell surface. Scale bar: $10 \mu \mathrm{m}$. (E) Quantification of DjP2X-A-positive cell population among DjPiwiA-positive cells. The number of cells was counted in the region in front of the pharynx using confocal microscopy $(n=4)$. The fraction of DjP2X-A-positive cells was $48.3 \pm 3.3 \%$. (F) Immuno-histochemistry of a transverse section anterior to the pharynx using anti-DjP2X-A antibody. (G) Merge of signals from anti-DjP2X-A (green) and DjPiwiA (magenta) antibody staining on the transverse section. Dorsal is to the top. $i$ : intestine. Scale bar: $200 \mu \mathrm{m}$

\section{Heterogeneous expression of DjP2X-A protein in the neoblast population}

Next we performed simultaneous whole-mount immunohistochemistry using anti-DjP2X-A antibody and the neoblast marker anti-DjPiwiAantibody (Shibata et al., 2010). By detailed observation of DjP2X-A-positive cells, we found heterogeneous expression of DjP2X-A protein in the neoblast population (Fig. 2). We found neoblasts expressing both DjPiwiA and DjP2X-A (Fig. 2 A,B,C, arrow), and neoblasts expressing only DjPiwiA but not DjP2X-A (Fig. 2 A,B,C, arrowhead). High magnification analysis revealed that DjP2X-A protein is localized on the cell surface, enclosing the DjPiwiA signal uniformly localized throughout the cytoplasm of neoblasts (Fig. 2D). These results indicate that DjP2X-A is localized at the membrane of neoblasts, like members of the P2X family proteins expressed in cells in other animals.

We counted the number of DjP2X-A-positive cells among DjPiwiA-positive cells, and found that about $48 \%$ of DjPiwiApositive cells (i.e., neoblasts) were also positive for DjP2X-A (Fig. 2E). This result is consistent with the observations made by single cell PCR analysis, in which about half of cells expressing DjpiwiA mRNA were positive for DjP2X-A mRNA (Shibata et al., 2012). Section immunohistochemistry using both anti-DjP2X-A antibody and anti-DjPiwiA antibody revealed that cells positive for both DjP2X-A and DjPiwiA were localized in the outermost layer of the mesenchymal space, near the epidermis, whereas many DjPiwiA-single-positive neoblasts were observed in a more internal region surrounding the intestine (Fig. 2 F,G).

\section{RNAi of DjP2X-A increases planarian fission frequency}

In order to elucidate the function of DjP2X-A, we conducted RNAi experiments. We employed a feeding RNAi method, in which dsRNA is introduced into planarians by mixing it with their food. We fed planarians dsRNA-containing liver three times in 1 week, and then amputated the planarians into three parts (anterior and posterior to the pharynx). The amputated fragments showed no defects and seemed to be able to regenerate normally within a week (data not shown).

Next, we performed long-term feeding of dsRNA without amputation. Planarians were fed dsRNA-containing food once per week for a month, after the third feeding of the initial week described above (taken as 0 day of RNAi). Surprisingly, we found that $D j P 2 X-A(R N A i)$ planarians underwent fission more frequently than control animals after the initial RNAi series (Fig. 3A). We counted the number of fission events in both control and $D j P 2 X-A(R N A i)$ animals for the entire length of the experiment ( $\mathrm{n}=30$ each). DjP2X-A(RNAi) planarians underwent fission about 28 times (2.57-fold higher than control), compared to about 10 times for control animals (Fig. 3A and Table 1). We performed the same experiment and included groups of $X$-ray-irradiated planarians. Five days after the initial week of RNAi feedings, control and $D j P 2 X-A(R N A i)$ planarians were exposed to $X$-rays in order to eliminate their neoblasts. We found that neither control nor $D j P 2 X-A(R N A i)$ X-ray-irradiated planarians ever fissioned, and they eventually died within 14 days after irradiation (Table 1). In contrast, non-irradiated $D j P 2 X-A(R N A i)$ planarians underwent fission 14 times, compared to 5 times for control animals, indicating that the increase in fission observed after $D j P 2 X-A$ RNAi occurs in a neoblast-dependent manner (Table1).

The increase in fission events observed in DjP2X-A(RNAi) did not result in smaller animals. We measured the fragments

TABLE 1

TOTAL NUMBER OF FISSION TIMES AFTER RNAi

\begin{tabular}{|c|c|c|c|c|c|c|}
\hline & exp.1 & & exp. 2 & & exp. 3 & \\
\hline & $\begin{array}{c}\text { Total \# } \\
\text { of fission times }\end{array}$ & X-ray & $\begin{array}{c}\text { Total \# } \\
\text { of fission times }\end{array}$ & X-ray & $\begin{array}{c}\text { Total \# } \\
\text { of fission times }\end{array}$ & X-ray \\
\hline control & 7 & - & 5 & - & $\begin{array}{c}0 \\
\text { (dead within 2weeks) }\end{array}$ & + \\
\hline$P 2 X(R N A i)$ & 18 & - & 14 & - & $\begin{array}{c}0 \\
\text { (dead within 2weeks) }\end{array}$ & + \\
\hline $\begin{array}{c}\text { cont. : } \\
\text { P2X(RNAi) }\end{array}$ & $1: 2.57$ & & $1: 2.8$ & & & \\
\hline
\end{tabular}

21 days after 3rd feeding 
A
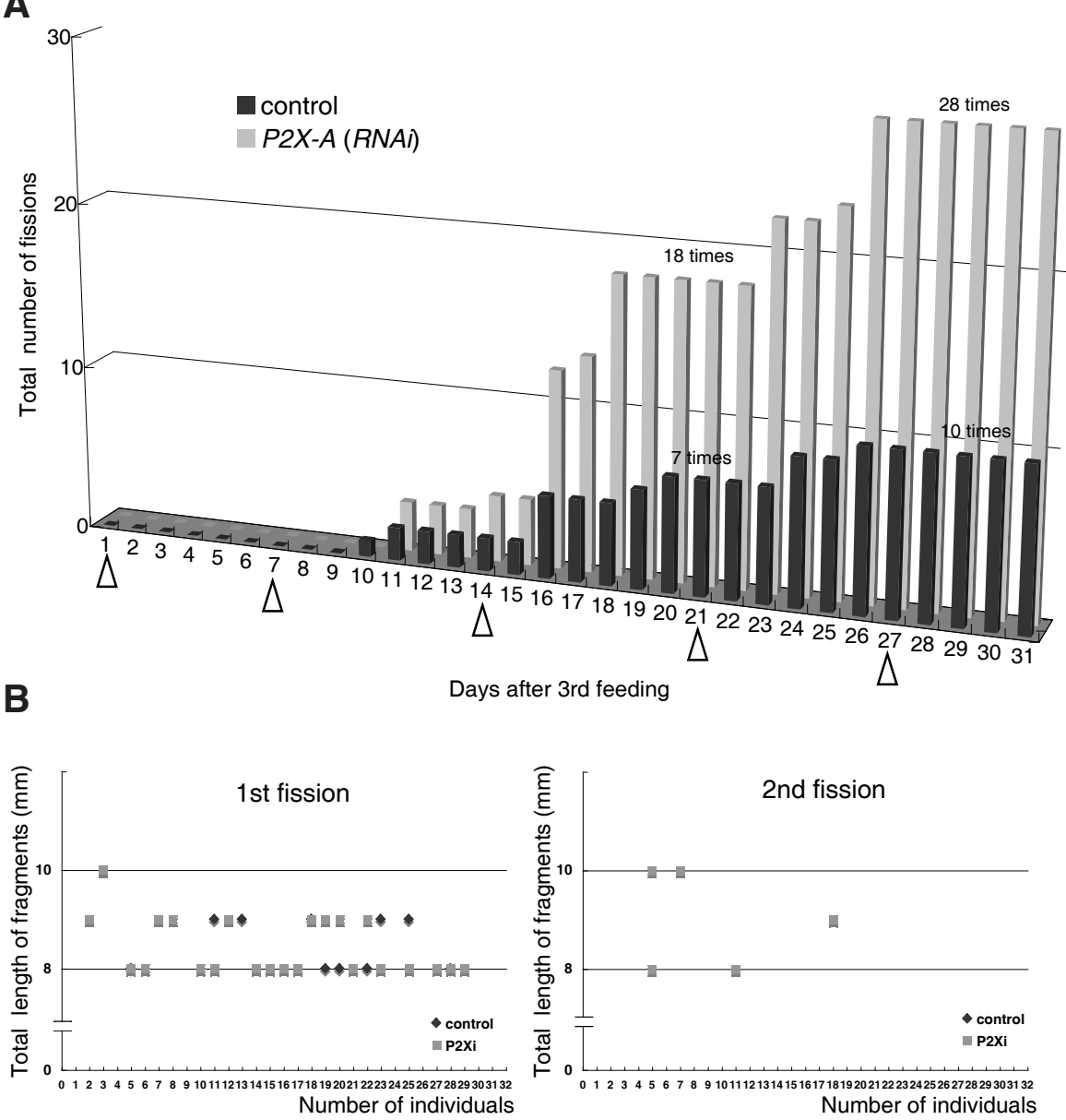

Fig. 3. Total fission events and size of planarians during the feeding RNAi. (A) After feeding food containing dsRNA three times in 1 week, planarians were fed food containing dsRNA every week (arrowheads), and their fission events were counted. A total of $30(6 \mathrm{~mm})$ animals were evaluated. (B) Total length of the fragments of planarians derived from fission. Anterior and posterior fragments from a single planarian were measured and the sum of the two lengths was plotted.

produced by fission in control and $D j P 2 X-A$ RNAi animals. In both the control and $D j P 2 X-A(R N A i)$ animals, the average length of the fragments after fission was over $8 \mathrm{~mm}(8-10 \mathrm{~mm})$, even in the case of fragments produced by a second fission (Fig. 3B). These results indicated that the increase in fission events did not occur at the expense of size, and suggested that the growth of the planarians was promoted by DjP2X-A RNAi.

\section{DjP2X-A expression negatively correlates with proliferative features}

Previously, it was reported that the number of neoblasts in the M-phase of the cell cycle increases transiently after feeding (Baguñà 1974; Kang and Sánchez Alvarado, 2009). This transient acceleration of neoblast proliferation is called the "mitotic burst". This mitotic burst is composed of two phases. The first phase peaks 12 to 24 hours after feeding, and the second wave 3 to 5 days after feeding. The animals return to a steady mitotic state 7 days after feeding, regardless of their body length (Baguñà 1974).

We observed that fission events tended to occur 2 days after every feeding (Fig. 3), and thus we speculated that DjP2X-A might be working by regulating the mitotic burst that occurs after feeding. To examine the relationship between DjP2X-A and cell proliferation, we analyzed the feeding-induced changes of two proliferative cell marker genes and $D j P 2 X-A$, by quantitative RT-PCR (qRT-PCR). We used Djpcna and DjMCM2 as proliferative cell marker genes, which are mainly expressed in the Sphase of the cell cycle in neoblasts (Hayashi et al., 2010). The expression level of Djpcna rapidly increased and peaked 12-24 hours after feeding, stayed above the steady state level until the third day after feeding, and reached a steady state level within 7 days (Fig. 4A). We also obtained similar results in the case of DiMCM2 (Fig. 4A and Fig. 5A). The transient increase in the expression levels of these DNA replication-related genes coincided with the mitotic burst observed by immunofluorescence with antibodies against the M-phase marker phospho-histone $\mathrm{H} 3(\mathrm{pH} 3)$ and shown in previous reports (Fig 4 A,B; Baguñà 1974; Kang and Sánchez Alvarado, 2009; Newmark and Sánchez Alvarado, 2000). Thus, like the M-phase marker $\mathrm{pH} 3$, the expression of proliferative cell marker genes Djpcna and DjMCM2 can be used to monitor increases in the mitotic cycling.

In contrast to the expression dynamics of proliferative cell markers, DjP2X-A expression declined slightly $12-24$ hours after feeding. Aslight increase in $D j P 2 X-A$ expression was observed 3 days after feeding. $D j P 2 X$-Aexpression continued to rise and seemed to be at its highest level 7 days after feeding (Fig. 4A). The expression pattern of $D j P 2 X-A$ appeared to be opposite to that of proliferative cell markers, suggesting a negative correlation between $D j P 2 X-A$ expression and the post-feeding mitotic burst.

In order to examine whether the localization or number of DjP2X-A-positive cells changed in response to feeding, we performed detailed immunohistochemistry on sections using anti-DjP2X-A antibody. No obvious change of the distribution of DjP2X-A-positive cells was observed (data not shown), and no significant change of the number of DjP2X-A-positive cells was detected after feeding (Fig. 4D). Double immunohistochemistry using anti-DjP2X-A and anti-pH3 antibodies revealed that there were not only $\mathrm{pH} 3 / \mathrm{DjP} 2 \mathrm{X}-\mathrm{A}$-double-positive cells (Fig. 4C arrowhead), but also pH3-single positive and DjP2X-A-single positive cells (Fig. 4C). However, during the mitotic burst, the population of DjP2X-A/pH3-double-positive cells increased gradually. The proportion of DjP2X-A-positive cells among $\mathrm{pH} 3$-positive cells was approximately $30 \%$ before feeding (Fig. 4E). Seven days after feeding, the proportion increased and reached approximately $56 \%$ (Fig. 4E; $p<0.05$ ), suggesting that DjP2X-A is involved in controlling cell proliferation after feeding.

DjP2X-A is involved in repressing post-feeding mitotic bursts To elucidate the relationship between cell proliferation and DjP2XA, we performed qRT-PCR analyses of proliferative cell markers 
in recently fed $D j P 2 X-A(R N A i)$ animals. We fed planarians food containing control or DjP2X-A dsRNA three times, and compared the expression of proliferative cell markers at several times after feeding with the expression just before feeding. We found that $D j P 2 X-A(R N A i)$ animals showed higher DjMCM2 expression levels than control animals, especially 1 to 7 days after feeding (Fig. 5 A,B). Similar results were obtained in analyses of Djpcna expression (data not shown), suggesting that proliferation, and not just $D j M C M 2$ expression, was higher in DjP2X-A(RNAi) than in control animals. Histological analysis using anti-pH3 antibody also showed that the number of pH3-positive cells was higher in DjP2X-A(RNAi) animals than in control animals 5 days after feeding (Fig. 5 C,D). These results show that $\mathrm{DjP} 2 \mathrm{X}$-A function is negatively associated with the mitotic burst after feeding.

Based on all these results, we propose that DjP2X-A negatively regulates the mitotic acceleration that occurs after feeding. Normally, neoblast proliferation is accelerated by feeding, and then deceler-
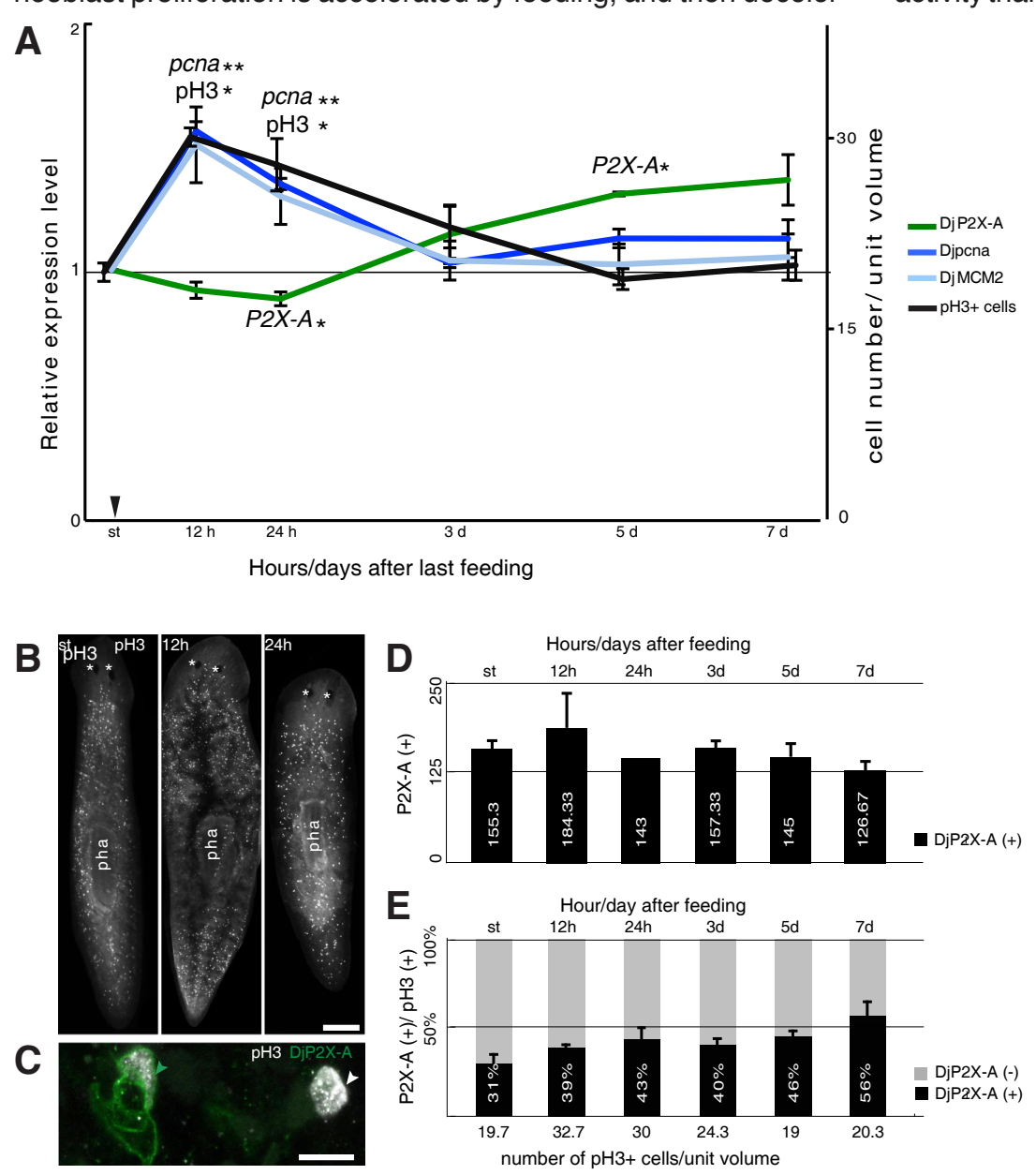

Fig. 4. Gene expression analyses and histological analyses of DjP2X-A after feeding. (A) Gene expression level analysis by qRT-PCR from three independent experiments. The value at each time is expressed relative to that in starved animals. st: starved. ${ }^{*} p<0.005$. ${ }^{*} p<0.05$ (B) Whole-mount immuno-histochemistry using anti-pH3 antibody after feeding Asterisk: eye. Scale bar: $500 \mu \mathrm{m}$. (C) Higher magnification view of whole-mount immunohistochemistry using anti-pH3 antibody and anti-DjP2X-A antibody. Arrowheads indicate anti-DjP2X-A/ anti-pH3 double-positive cells. Scale bar: $50 \mu \mathrm{m}$. (D) Counting of DjP2X-Apositive cells in front of the pharyngeal region after feeding $(n=3)$. Unit volume: $1.1 \times 10^{-2}$ $\mathrm{mm}^{3}$. (E) Quantification of DjP2X-A-positive cells among the $\mathrm{pH} 3$-positive cells in front of the pharyngeal region after feeding $(n=3)$. Unit volume: $1.1 \times 10^{-2} \mathrm{~mm}^{3}$. ated by DjP2X-A after feeding. DjP2X-A(RNAi) planarians seem to of neoblast proliferation ultimately leads to the increased fission

\section{DjP2X-A functions in activation of the cell cycle in starved imals}

The above experiments clearly showed that DjP2X-A functions Wection of dsRNA, a method that does not involve feeding and

urprisingly, $D j P 2 X-A(R N A i)$ animals showed lower proliferative control animals. The Djpcna expression level in $D j P 2 X$ $A(R N A i)$ planarians was approximately $40 \%$ of that seen in control animals (Fig. 6A). This result agreed with histological analyses using BrdU labeling. The number of BrdU-labeled cells was significantly lower in $D j P 2 X-A(R N A i)$ planarians when compared to control animals, whereas pH3-positive cells appeared to be only slightly decreased (Fig. 6 B,C). This decrease of BrdU labeling indicated that DjP2X-A is required to maintain the proliferative activity of neoblasts under starved conditions. Additionally, depletion of $D j P 2 X-A$ by dsRNA injection did not have an effect on regeneration (data not shown), suggesting that $D j P 2 X-A$ is not critical for cell differentiation.

Finally, we fed planarians that had previously undergone control or DjP2X-A dsRNA injection, and analyzed Djpcna expression at various times thereafter. Before feeding, the Djpcna expression level in DjP2X-A(RNAi) planarians was $40 \%$ of the level seen in the control animals. However, the expression of Djpcna in DjP2X-A(RNAi) planarians increased after feeding and ultimately became comparable to that seen in control animals by the seventh day after feeding (Fig. 6D).

Based on these results, we propose that DjP2XA functions as a bidirectional cell-cycle modulator depending on nutrient availability: DjP2X-A works as a positive regulator under starved conditions and a negative regulator under eutrophic conditions.

\section{Discussion}

Here, we demonstrated heterogeneous expression and functions of DjP2X-A in the neoblasts of $D$. japonica. The extracellular ATP-binding region and cysteine residues needed to form disulfide bonds are conserved in the DjP2X-A amino acid sequence, suggesting that this protein can bind to extracellular ATP and work as an ionotropic receptor, like its homologs in other animals. The localization of the DjP2X-A protein on the membrane of neoblasts also supports this notion. It has been reported that there are seven human P2X family genes, and that their expression 
is widely distributed throughout the entire human body. Each of them forms hetero-trimers to work as ionotropic receptors (Mio et al., 2009). We also found five additional P2X family genes in $D$. japonica (Fig. S1); however, none of them were expressed in the neoblasts (Sakurai, unpublished data), suggesting that DjP2X-A might form homo-trimers on the neoblast membrane.

It is known that micro-environmental factors, such as growth factors or peptides, can regulate the cell proliferation and differentiation of stem cells. Recent findings have shown that various growth factors are involved in specifying the body polarity of planarians, such as the antero-posterior and dorsal-ventral axes. Hh (Hedgehog) and Wnt family members induce the differentiation of posterior cells from neoblasts (Gurley et al., 2008; Yazawa et al., 2009). BMP (Bone morphogenetic protein) is involved in dorsal cell specification of neoblasts (Molina et al., 2007). Although it is clear that these factors can be expected to influence the cell fate via interactions with factors present in the cell membrane of neoblasts, the implications for cell proliferation of the neoblasts are still unclear. Here, we report the possibility that small molecules expected to exist in the mesenchymal space, such as ATP and
A

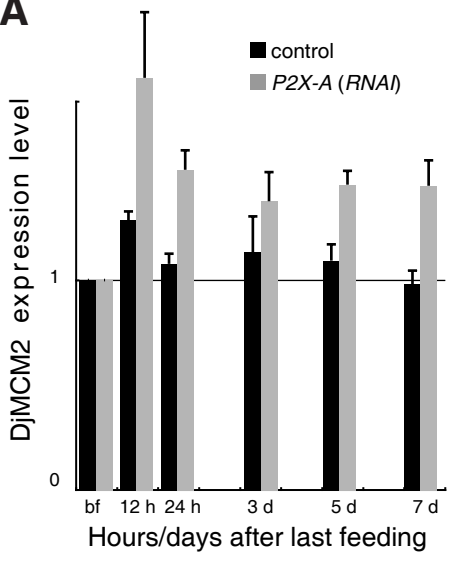

C
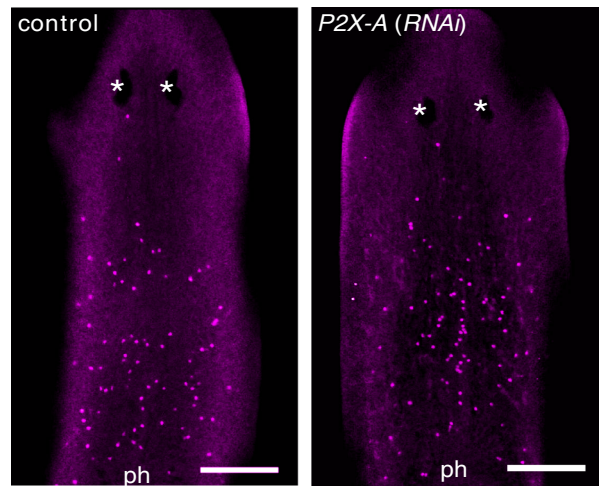

B

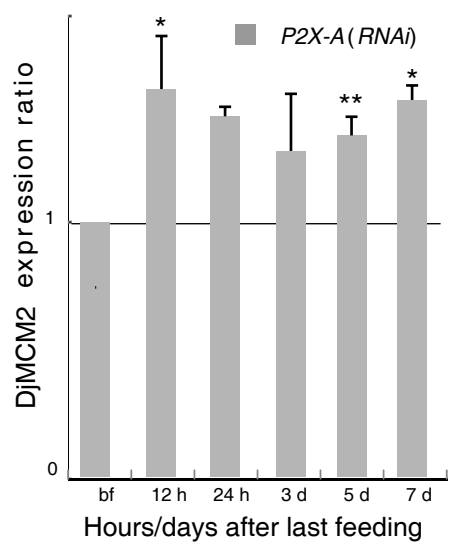

D

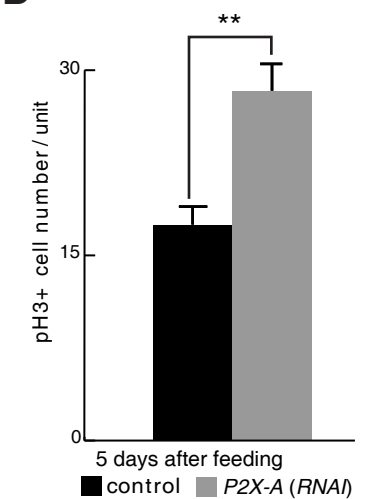

Fig. 5. Cell cycle defects observed after feeding DjP2X-A dsRNA. (A) and (B) Expression level transition of Djpcna after third dsRNA feeding. (A) Relative expression level of DjMCM2 after DjP2X(RNAi) by qRT-PCR $(n=4)$. Starved animals (st) were used to obtain the relative value. Both DjP2X-A(RNAi) and control animals were assayed after the third feeding. (B) Expression level of DjMCM2 in $\mathrm{DjP} 2 \mathrm{X}(\mathrm{RNAi})$ animals relative to that in control animals. ${ }^{*} p<0.05 .{ }^{*} p<0.01$. (C) Images showing pH3-positive cells in both DjP2X-A(RNAi) and control animals at 5 days after the third feeding of dsRNA. Dorsal view. pha: pharynx. asterisk: eye. Scale bar: $250 \mu \mathrm{m}$. (D) Quantification of the number of pH3-positive cells ( $n=3)$. ${ }^{*} p<0.05$. Unit volume: $1.1 \times 10^{-2} \mathrm{~mm}^{3}$. ions, control cell proliferation via factors present in the membrane of neoblasts. This might be an important finding for understanding the relationship between two fundamental behaviors: the cell proliferation and differentiation of stem cells.

\section{DjP2X-A is involved in transient acceleration of neoblast proliferation after feeding}

It has been reported that neoblasts show transient acceleration of proliferation after feeding, and return to a steady state of proliferation within a week (Baguñá, 1974). This transition could be monitored by quantification of the expression levels of Djpcna and DjMCM2 in the present study (Fig. 4A), or by counting the number of pH3-positive cells (Kang and Sánchez Alvarado, 2009). We found that the expression level of $D j P 2 X-A$ showed a negative correlation with the expression of cell proliferation markers: the $D j P 2 X-A$ expression level was down-regulated when cell proliferation was accelerated, and up-regulated when the acceleration of cell proliferation subsequently decreased (Fig. 4A). This negative correlation was also observed during early regeneration (Fig. $1 \mathrm{C}, \mathrm{D}, \mathrm{E})$, suggesting that cue molecules that regulate the first mitotic burst might down-regulate expression of $D j P 2 X-A$. Furthermore, the number of DjP2X-A/pH3 double-positive cells increased from 24 hours to 7 days after feeding (Fig. $4 \mathrm{E})$. From these results, we speculate that DjP2X-A is involved in the accelerated proliferation of neoblasts after feeding and is regulated by signals similar to those causing this acceleration. Furthermore, no obvious change of the number of DjP2X-A-positive cells was observed after feeding, suggesting that increased $D j P 2 X-A$ expression by the neoblasts might occur after feeding.

We discovered that $D j P 2 X-A(R N A i)$ animals showed a higher level of DjMCM2 expression and increased number of mitotic cells compared to control animals after feeding (Fig.5). These increases caused by RNAi were not observed during the initial acceleration of proliferation. This suggests that the function of DjP2X-A as an anti-proliferator is not always active, but rather works to slow the acceleration of proliferation resulting from some stimuli (such as food intake) to a normal steady state. Indeed, it has been reported that the $\mathrm{P} 2 \mathrm{X}$ negatively regulates cell proliferation by regulating the $\mathrm{Ca} 2+$ current in human mesenchymal stem cells (Coppi et al., 2007). We also observed that $D j P 2 X-A$ expression was negatively correlated with the acceleration of proliferation during regeneration. Rat P2X7 has been reported to be involved in the differentiation of rat astrocytes in which ERK1 and 2 have been activated (Panenka et al., 2001). $D j P 2 X-A(R N A i)$ animals did not show obvious differences in the regeneration compared to control planarians. This result rules out the possibility the DjP2X-A functions in differentiation. Based on these results, we conclude that expression of DjP2X-A is up-regulated after the acceleration of proliferation, and that DjP2X-A then works to slow down proliferation.

\section{DjP2X-A as a cell-cycle activity modulator}

Although our data revealed that DjP2X-A works to negatively regulate cell proliferation after feeding, we also observed that $D j P 2 X-A(R N A i)$ animals under starved conditions in injection RNAi experiments showed lowered 
proliferative activity (Fig. 6). In murine microglia, P2X acts as a bifunctional receptor; for example, it can behave either as a deathinducing or a growth-promoting receptor depending on the level of its activation (Adinolfi et al., 2005; Bianco et al., 2006). Accordingly, we speculate that $\mathrm{DjP} 2 \mathrm{X}-\mathrm{A}$ changes its function in cell proliferation according to the cellular environment of the neoblasts: it works as a positive regulator in a starved environment and a negative regulator in a eutrophic environment.

How does DjP2X-A change its function in regulating proliferation according to the environment? It can be predicted that differences of extracellular ATP concentration lead to changes in the permeability of ions by affecting the activity of DjP2X-A (Fig. 7). In many types of cells in mammals, stimulation of P2X7 by ATP affects the permeability of ions into the cells, which in turn affects various cell behaviors, including cell proliferation (Adinolfi et al., 2005). Accumulating evidence shows that in human neural stem cells, ions from various types of ion channels regulate proliferation (Yasuda \& Adams 2010). Thus, the accelerated cell proliferation of the stem cells that occurs after feeding might be suppressed by higher concentrations of ions via DjP2X-A (Fig. 7A). In contrast, the extracellular ATP concentration is probably low in starved animals, and therefore DjP2X-A passes only a small amount of ions, which seems likely to be an appropriate amount of ions to keep the proliferation of the neoblasts at the steady state (Fig 7B). Thus, DjP2X-A might have bimodal and opposing functions affecting the proliferation of the neoblasts according to nutrient conditions.

What kind of molecular mechanism could induce acceleration of cell proliferation after feeding? Because the expression level of $D j P 2 X-A$ was decreased during bursts of proliferation, and the neoblasts around the intestine did not express DjP2X-A, the molecular mechanism regulating cell cycle acceleration is also

A

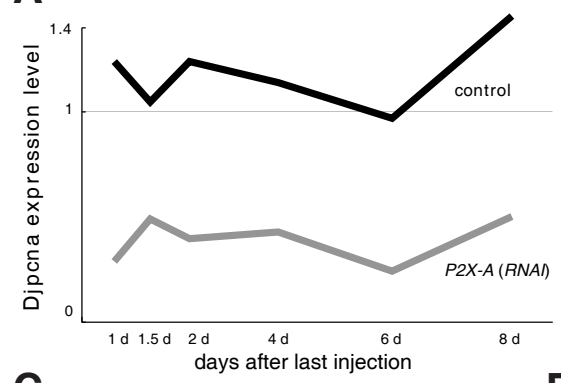

C

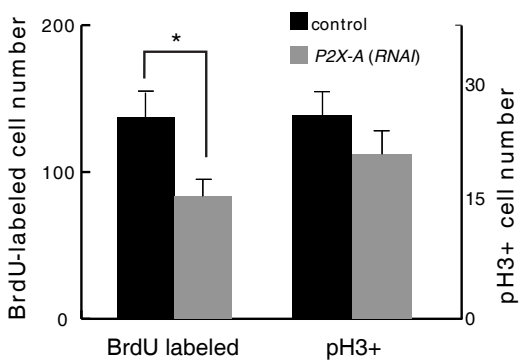

D
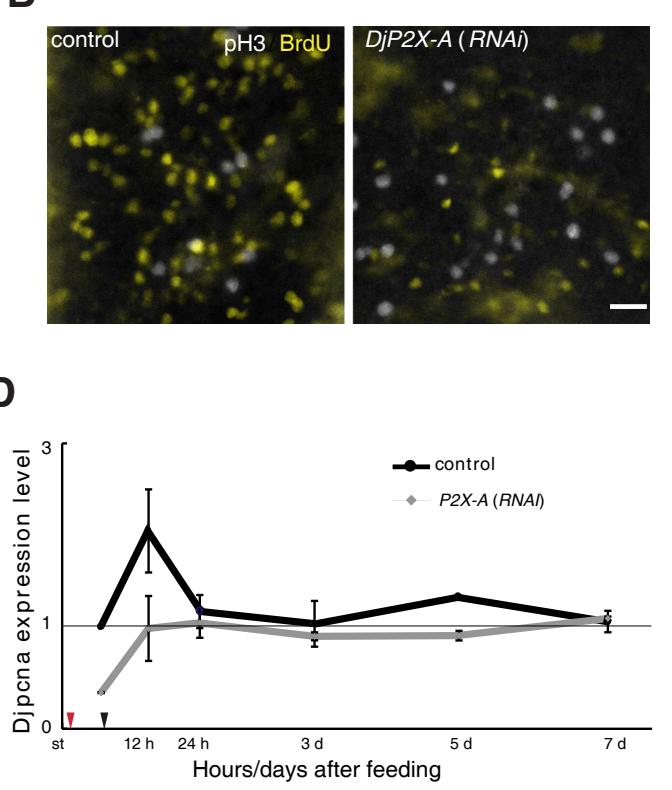

Fig. 6. DjP2X-A (RNAi) defects in starved condition. (A) Expression level of Djpcna in animals subjected to dsRNA injection. Red arrowhead indicates time of third dsRNA injection. (B,C) Quantification of pH3-positive cells and of BrdU-labeled cells in both DjP2X-A(RNAi) and control animals at 1 day after the third dsRNA injection ( $n=3)$. Dorsal view. Unit volume: $1.1 \times 10^{-2} \mathrm{~mm}^{3}$. ${ }^{*} p<0.05$. Scale bar: $75 \mu \mathrm{m}$. (D) Expression level transition of Djpcna after dsRNA injection and feeding. Red arrowhead indicates time of the third dsRNA injection. Black arrowhead indicates time of feeding.
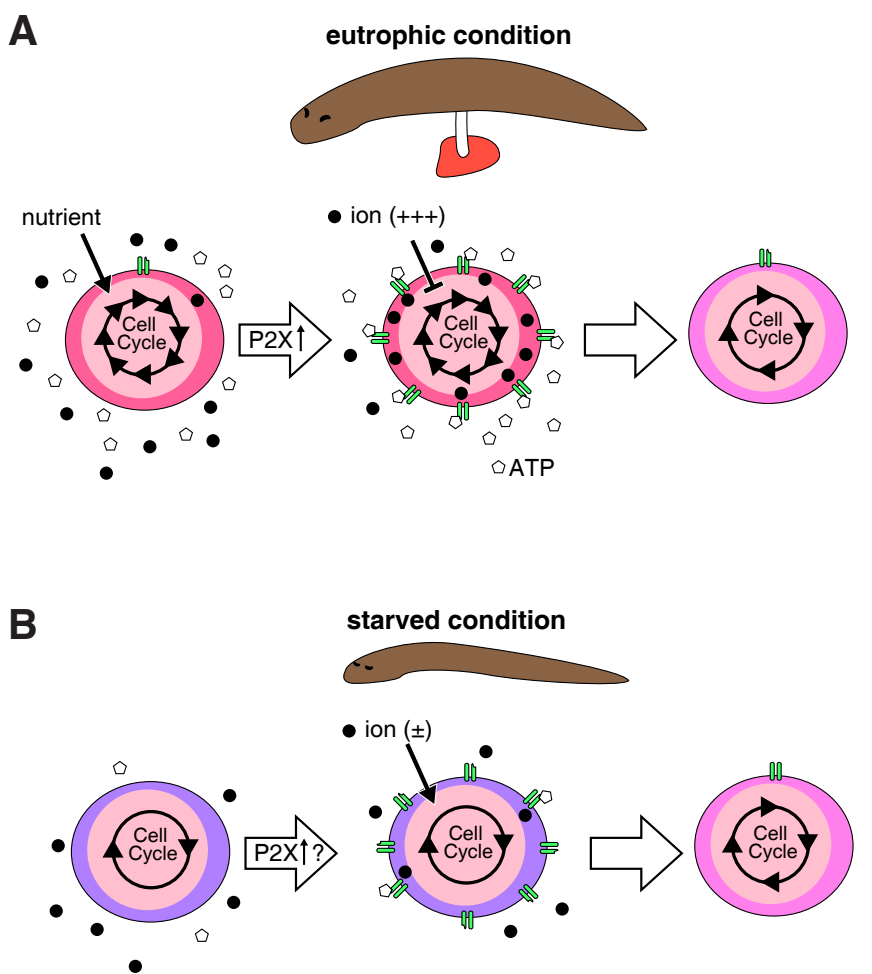

Fig. 7. A schematic illustration of predicted DjP2X-A function. (A) Eutrophic condition and (B) starved condition.

pated to regulate the expression of $D j P 2 X-A$. One possible candidate mechanism involves the mTORpathway, which is known to have an important role in proliferation through regulating metabolic activity in various animals, including invertebrate animals such as Drosophila Melanogasterand Caenorhabditiselegans (Hafen 2004; Stiles et al., 2004). It was reported that P2X7 transfected into HEK cells is downregulated by PIP2, which is upstream of the mTOR pathway (Zhao etal., 2007). It has been reported that planarians have IGFR, AKT and PTEN homolog genes, which are involved in the mTOR pathway (Ogawa et al., 2002; Oviedo et al., 2008). Smed-Akt acts as a positive regulator of neoblast proliferation, and its expression is down-regulated by Smed-PTEN as well as the PI3K-Akt-TOR pathway in mammalian stem cells, suggesting that this pathway might accelerate neoblast proliferation after feeding in planarians (Sabatini 2006; Oviedo et al., 2008). Thus, it would be of interest to investigate the expression of $D j P 2 X-A$ in planarians with a disrupted mTOR pathway.

\section{DjP2X-A RNAi increases planarian fis- sion frequency}

Although the precise mechanism of planarian fission is not known, it is known that fission occurs in a manner dependent 
on body length; in other words, dependent on the growth of body size. The first phenotype observed in DjP2X-A(RNAi) was increased fission frequency (Fig. 3). Indeed, DjP2X-A(RNAi) animals produced by feeding dsRNA had a higher rate of proliferation than control animals. The differentiation of the neoblasts seemed to be normal. The planarian body size is directly proportional to the total cell number (Takeda et al., 2009). Therefore, we speculate that $D j P 2 X-A(R N A i)$ animals might have an increase of total body cells and tend to grow faster than control animals. Actually, we measured and summed the length of both fragments just after fission, and observed that all of the planarians that underwent fission were over $8 \mathrm{~mm}$ long (Fig. 3B). This body length may be the threshold for fission, and our results strongly suggest that $D j P 2 X-A(R N A i)$ animals grow and reach this "threshold" faster than control animals.

Overall, this study has given a glimpse into the relationship between the regulation of proliferation by DjP2X-A and fission. In addition, it has shown that the bidirectional function of DjP2X-A appears to contribute to the mechanism of the maintenance of the stem cell proliferation. More detailed analyses of how the acceleration and deceleration of the cell cycle are regulated by the microenvironment will give new insights into molecular and cellular mechanisms of not only asexual reproduction, but also stem cell dynamics.

\section{Materials and Methods}

\section{Biological samples}

Aclonal strain of planarian Dugesiajaponica, sexualizing special planarian (SSP) $(2 n=16)$, was cultured at $23^{\circ} \mathrm{C}$ in water sterilized by autoclaving. Chicken liver was fed to planarians once a week or once every 2 weeks. Animals had been starved for at least 1 week before all experiments.

\section{$X$-ray irradiation}

Animals placed on wet filter paper on ice were irradiated with 160 Roentgen of X-rays using an X-ray generator (SOFTEX B-5; SOFTEX, Tokyo, Japan).

\section{Feeding RNA interference}

AMEGAscript Kit (Ambion) was used for double-stranded RNA(dsRNA) synthesis. The linearized DNA with a T7 or T3 promoter site was used as a template for antisense or sense RNA transcription. Antisense or sense RNA was transcribed for 3 hours at $37^{\circ} \mathrm{C}$. After RNA transcription, RNAs were treated with DNAse TURBO to remove the template DNA, and the RNA transcripts were mixed and extracted with phenol/chloroform. Mixed RNA transcripts were denatured for 20 minutes at $65^{\circ} \mathrm{C}$ and annealed for 40 minutes at $37^{\circ} \mathrm{C}$. The resultant dsRNA was precipitated with ethanol and dissolved in water at $2.0 \mu \mathrm{g} / \mu \mathrm{L}$.

dsRNA was used to knock down the target genes by RNAi. Twenty-five microliters of chicken liver solution, $5 \mu \mathrm{L}$ of $2 \%$ agarose and $5 \mu \mathrm{L}$ of $2 \mu \mathrm{g} / \mu \mathrm{L}$ dsRNA were mixed and presented to a group of 15 planarians. This food solution was prepared in small aliquots (about $35 \mu \mathrm{L}$ ) and frozen at $-30^{\circ} \mathrm{C}$ for storage. Two successive feedings were conducted at 3-day intervals after the 1st feeding. Control animals were fed dsRNA of EGFP.

\section{Injection RNA interference}

RNA interference was also performed by injecting dsRNA directly, prepared as described above, into the planarian intestine. Two successive injections were conducted at intervals of one day after the first injection. Control animals were injected with dsRNA of EGFP.

\section{Whole-mount in situ hybridization}

Whole-mount in situ hybridization was performed as described previously (Umesono et al., 1997). The plasmid pBluescript SK containing the gene of interest was used as the template for RNA probe synthesis. The plasmid was linearized with Notl at the 5' region of the target genes. The linearized DNA was used as a template for antisense RNA transcription by T7 RNA polymerase (Fermentas). Antisense RNA probe was labeled with digoxigenin (Dig) according to the manufacturer's instructions (Roche Diagnostics).

Animals were treated with $2 \% \mathrm{HCl}$ in $5 / 8$ Holtfreter's solution for 5 minutes to clear epidermal mucus, and fixed in $4 \%$ paraformaldehyde $/ 5 \%$ methanol in $5 / 8$ Holtfreter's solution for 1 hour at $4^{\circ} \mathrm{C}$. Then, the samples were bleached with $5 \% \mathrm{H}_{2} \mathrm{O}_{2}$ in methanol overnight at room temperature under fluorescent light. Bleached samples were treated with 1:1 xylene:ethanol solution for 30 minutes at room temperature and rinsed in $100 \%$ ethanol for 30 minutes at $4^{\circ} \mathrm{C}$. Then, the samples were rehydrated through a graded ethanol series (75\%, 50\% and $25 \%$ ) in $5 / 8$ Holtfreter's solution for 30 minutes each at $4{ }^{\circ} \mathrm{C}$. The rehydrated samples were rinsed in TPBS for 30 minutes at $4^{\circ} \mathrm{C}$ and permeabilized by $2 \mu \mathrm{g} / \mathrm{ml}$ proteinase $\mathrm{K}$ in TPBS treatment for 7 minutes at $37^{\circ} \mathrm{C}$. Then, the samples were post-fixed in $4 \%$ paraformaldehyde / $5 \%$ methanol in $5 / 8$ Holtfreter's solution for 30 minutes at $4^{\circ} \mathrm{C}$ and rinsed in TPBS twice each for 5 minutes at $4^{\circ} \mathrm{C}$. Next, the samples were soaked in prehybridization solution for 1 hour at $55^{\circ} \mathrm{C}$, and incubated with Dig-labeled antisense RNA probes (probes were denatured previously for 20 minutes at $65^{\circ} \mathrm{C}$ ) in hybridization solution for 36 hours at $55^{\circ} \mathrm{C}$. Then, the samples were washed in wash solution 8 times for 30 minutes each at $55^{\circ} \mathrm{C}$ and rinsed in Buffer I, 2 times for 5 minutes each at room temperature. The rinsed samples were treated with Buffer II for blocking for 1 hour at room temperature and treated with 1/2000 alkaline phosphatase-conjugated anti- Digoxigenin antibody (Roche Diagnostics) in Buffer I overnight at $4^{\circ} \mathrm{C}$. Samples were rinsed in Buffer I four times for 30 minutes each at room temperature and washed in TMN solution two times for 5 minutes each at room temperature. In order to detect color signals, a mixture of $3.5 \mu \mathrm{g} / \mathrm{ml}$ 5-bromo-4-chloro-3-indolyl phosphatase (Roche Diagnostics) and $1.8 \mu \mathrm{g} /$ $\mathrm{ml}$ 4-nitro blue tetrazolium chloride (Roche Diagnostics) in TMN solution was used. After the detection, TE buffer was used to stop the reaction and the samples were stored in TE buffer at $4^{\circ} \mathrm{C}$.

\section{Antibody}

A cDNA fragment encoding DjP2X-A was amplified by PCR with primers 5'-TTTGGATCCAAACTCAATGGTATTGGGATGACG-3' and 5'-TTTAAGCTTGAATAGATCTCTGTATTCTTTGG-3' using plasmid DNA as a template, and digested with $\mathrm{BamHI}$ and HindIII. The digested fragments were sub-cloned into pQE30 vector (QIAGEN). Recombinant6xHis-DjP2X-A protein was purified and used as antigen. Mouse monoclonal antibodies for DjP2X-A were generated by MBL (Nagoya, Japan).

\section{Whole-mount immunohistochemistry}

The sample animals were treated with $2 \% \mathrm{HCl}$ in $5 / 8$ Holtfreter's solution for 5 minutes to clear epidermal mucus, and fixed in Carnoy's solution (60\% ethanol $/ 30 \%$ chloroform $/ 10 \%$ acetic acid) for 2 hours at $4{ }^{\circ} \mathrm{C}$. Then, the samples were bleached with $5 \% \mathrm{H}_{2} \mathrm{O}_{2}$ in methanol overnight at room temperature under fluorescent light. Bleached samples were treated with $1: 1$ xylene:ethanol solution for 30 minutes at room temperature and rinsed in $100 \%$ ethanol for 30 minutes at $4^{\circ} \mathrm{C}$. The samples were rehydrated through a graded ethanol series $(75 \%, 50 \%$ and $25 \%)$ for 30 minutes each at $4^{\circ} \mathrm{C}$. The rehydrated samples were rinsed in TPBS for 30 minutes at $4^{\circ} \mathrm{C}$ and permeabilized with $2 \mu \mathrm{g} / \mathrm{ml}$ proteinase $\mathrm{K}$ in TPBS treatment for 7 minutes at $37^{\circ} \mathrm{C}$. Then, the samples were post-fixed in $4 \%$ paraformaldehyde $/ 5 \%$ methanol in $5 / 8$ Holtfreter's solution for 30 minutes at $4^{\circ} \mathrm{C}$ and rinsed in TPBS twice at $4^{\circ} \mathrm{C}$ for 5 minutes each. For blocking, the samples were soaked in 10\% goat serum in TPBS for 30 minutes at room temperature. After blocking, the samples were incubated in $10 \%$ goat serum in TPBS containing $1 / 1000$ diluted primary antibody overnight at $4^{\circ} \mathrm{C}$. The samples were rinsed in TPBS five times for 30 minutes each at room temperature, and incubated in $10 \%$ goat serum in TPBS containing 1/1000 fluorescent-labeled goat secondary antibody (Alexa Fluor 594 or Alexa Fluor 488 (Molecular Probes)) and $1 / 1000$ Hoechst 33342 (Calbiochem) overnight at $4^{\circ} \mathrm{C}$. Finally, 
the samples were rinsed in TPBS four times for 30 minutes each at room temperature, and mounted with Fluorescent Mounting Medium (Dako).

\section{BrdU incorporation and detection}

Bromo-2'-deoxyuridine (BrdU) (Sigma-Aldrich) was dissolved at $10 \mathrm{mg} /$ $\mathrm{ml}$ in water and injected into the planarian intestine. The injected animals were incubated at $23^{\circ} \mathrm{C}$ in culture water. The animals were then treated with $2 \% \mathrm{HCl}$ in $5 / 8$ Holtfreter's solution for 5 minutes to clear epidermal mucus, and fixed in $4 \%$ paraformaldehyde / $5 \%$ methanol in $5 / 8$ Holtfreter's solution for 1 hour at $4^{\circ} \mathrm{C}$. Immunohistochemistry was performed as described above. After incubation with secondary antibody, samples were post-fixed in $4 \%$ paraformaldehyde $/ 5 \%$ methanol in $5 / 8$ Holtfreter's solution for 15 minutes at $4^{\circ} \mathrm{C}$ and rinsed in TPBS twice at $4^{\circ} \mathrm{C}$ for 5 minutes. Samples were then rinsed twice with TPBS for 30 minutes each, and treated with $2 \mathrm{~N}$ $\mathrm{HCl}$ for 30 minutes at room temperature. After they were rinsed two times with TPBS for 30 minutes each at room temperature, the samples were blocked in 10\% goat serum in TPBS for 30 minutes at room temperature. After blocking, the samples were incubated in 10\% goat serum in TPBS containing $1 / 25$ diluted anti-BrdU antibody (Becton, Dickinson) overnight at $4^{\circ} \mathrm{C}$. The next day, the samples were rinsed in TPBS four times for 30 minutes each at room temperature, and BrdU signals were detected using a TSA labeling Kit No. 2 (Molecular Probes).

\section{Section immunohistochemistry}

The sample animals were fixed in Carnoy's solution (60\% ethanol / $30 \%$ chloroform $/ 10 \%$ acetic acid) for 2 hours at $4^{\circ} \mathrm{C}$. The fixed samples were dehydrated with ethanol and xylene solutions of gradually increasing concentration. Then the dehydrated samples were embedded in paraffin and sectioned at $10 \mu \mathrm{m}$. Paraffin was removed from the sections with xylene and a series of ethanol solutions of gradually decreasing concentration. Then the sections were washed in TPBS and autoclaved in $10 \mathrm{mM}$ citric acid buffer $\left(\mathrm{pH} \mathrm{6.0)}\right.$ ) for 10 minutes at $120^{\circ} \mathrm{C}$ and washed in TPBS. For blocking, the sections were soaked in $10 \%$ goat serum in TPBS for 30 minutes at room temperature. After blocking, the sections were incubated in $10 \%$ goat serum in TPBS containing $1 / 1000$ primary antibody overnight at $4^{\circ} \mathrm{C}$. The next day, the sections were rinsed in TPBS five times for 30 minutes each at room temperature, and incubated in $10 \%$ goat serum in TPBS containing 1/1000 diluted fluorescent-labeled goat secondary antibody (Alexa Fluor 594 / Alexa Fluor 488 (Molecular probe)) overnight at $4^{\circ} \mathrm{C}$. The sections were rinsed in TPBS three times for 10 minutes each at room temperature, and mounted in Fluorescent Mounting Medium (Dako).

\section{Quantitative real-time PCR analysis}

Total RNA was extracted by using ISOGEN-LS (Wako) following the manufacturer's protocol. cDNA was synthesized using a QuantiTect Reverse Transcription Kit ${ }^{\circ}$ according to the manufacturer's instructions (QIAGEN). The synthesized cDNA was appropriately diluted, and used for gene expression analysis by quantitative real-time PCR. Reactions were carried out in $10 \mu$ l of real-time PCR mixture containing $1 \times$ QuantiTect SYBR green PCR master mix (QIAGEN), $0.3 \mu \mathrm{M}$ gene-specific forward/reverse primers and $1 \mu \mathrm{L}$ of diluted cDNA template by incubation in an ABI PRISM $7900 \mathrm{HT}$ (Applied Biosystems). The reactions were carried out as follows: $50^{\circ} \mathrm{C}$ for 2 minutes, $95^{\circ} \mathrm{C}$ for 15 minutes, 50 cycles of $95^{\circ} \mathrm{C}$ for 15 seconds, $60^{\circ} \mathrm{C}$ for 30 seconds, $72^{\circ} \mathrm{C}$ for 1 minute.

The forward and reverse primer sets for the investigated genes are listed below (5' to 3').

G3PDH

FW: ACCACCAACTGTTTAGCTCCCTTAG

RV: GATGGTCCATCAACAGTCTTTTGC

Djpcna

FW: ACCTATCGTGTCACTGTCTTTGACCGAAAA

RV: TTCATCATCTTCGATTTTCGGAGCCAGATA

DjMCM2

FW: CGCTGTTGGACAAGGTCAGAAGAATGAACA

RV: CCAGAAACACAAATCTACATCTTCCAAAGG
$D j P 2 X-A$

FW: GATTTCAACAATGGAATGAATTTTAGATA

RV: AAAATGTGAAACAAGTAGCAGGATCA

\section{Acknowledgements}

We thank Dr. Labib Rouhana and Dr. Elizabeth Nakajima for critical reading of the manuscript and all other laboratory members for their help and encouragement. This work was supported by a Grant-in-Aid for Creative Scientific Research (17GS0318) to K. A., a Grant-in-Aid for Scientific Research on Innovative Areas "RNA regulation" (No. 20112006) to N.S., and Global COE Program A06 of Kyoto University.

\section{References}

ADINOLFI, E., PIZZIRANI, C., IDZKO, M., PANTHER, E., NORGAUER, J., DI VIRGILIO, F. and FERRARI, D. (2005). P2X(7) receptor: Death or life? Purinergic Signal 1: 219-227.

AGATA, K., NAKAJIMA, E., FUNAYAMA, N., SHIBATA, N., SAITO, Y. and UMESONO, Y. (2006). Two different evolutionary origins of stem cell systems and their molecular basis. Semin Cell Dev Biol 17: 503-509.

BAGUNA, J. (1974). Dramatic mitotic response in planarians after feeding, and a hypothesis for the control mechanism. J Exp Zool 190: 117-122.

BAGUNA, J. and ROMERO, R. (1981). Quantitative analysis of cell type during growth, degrowth and regeneration in the planarians Dugesia mediterranea and Dugesia tigrina. Hydrobiologica 84: 181-194.

BIANCO, F., CERUTI, S., COLOMBO, A., FUMAGALLI, M., FERRARI, D., PIZZIRANI, C., MATTEOLI, M., DI VIRGILIO, F., ABBRACCHIO, M.P. and VERDERIO, C. (2006). A role for P2X7 in microglial proliferation. J Neurochem 99: 745-758.

COPPI, E., PUGLIESE, A.M., URBANI, S., MELANI, A., CERBAI, E., MAZZANTI, B. BOSI, A., SACCARDI, R. and PEDATA, F. (2007). ATP modulates cell proliferation and elicits two different electrophysiological responses in human mesenchymal stem cells. Stem Cells 25: 1840-1849.

FUKUMURA, R., TAKAHASHI, H., SAITO, T., TSUTSUMI, Y., FUJIMORI, A., SATO, S., TATSUMI, K., ARAKI, R. and ABE, M. (2003). A sensitive transcriptome analysis method that can detect unknown transcripts. Nucleic Acids Res 31: e94.

GURLEY, K.A., RINK, J.C. and SANCHEZ ALVARADO, A. (2008). Beta-catenin defines head versus tail identity during planarian regeneration and homeostasis. Science 319: 323-327.

HAFEN, E. (2004). Cancer, type 2 diabetes, and ageing: news from flies and worms. Swiss Med Wkly 134: 711-719.

HAYASHI, T., SHIBATA, N., OKUMURA, R., KUDOME, T., NISHIMURA, O., TARUI, H. and AGATA, K. (2010). Single-cell gene profiling of planarian stem cells using fluorescent activated cell sorting and its "index sorting" function for stem cell research. Dev Growth Differ 52: 131-144.

KANG, H. and SANCHEZ ALVARADO, A. (2009). Flow cytometry methods for the study of cell-cycle parameters of planarian stem cells. Dev Dyn 238: 1111-1117.

MIO, K., OGURA, T., YAMAMOTO, T., HIROAKI, Y., FUJIYOSHI, Y., KUBO, Y. and SATO, C. (2009). Reconstruction of the P2X(2) receptor reveals a vase-shaped structure with lateral tunnels above the membrane. Structure 17: 266-275.

MOLINA, M.D., SALO, E. and CEBRIA, F. (2007). The BMP pathway is essential for re-specification and maintenance of the dorsoventral axis in regenerating and intact planarians. Dev Biol 311: 79-94.

NEWMARK, P.A. and SANCHEZ ALVARADO, A. (2000). Bromodeoxyuridine specifically labels the regenerative stem cells of planarians. Dev Biol 220: 142-153.

OGAWA, K., KOBAYASHI, C., HAYASHI, T., ORII, H., WATANABE, K. and AGATA, K. (2002). Planarian fibroblast growth factor receptor homologs expressed in stem cells and cephalic ganglions. Dev Growth Differ 44: 191-204.

OVIEDO, N.J., NEWMARK, P.A. and SANCHEZ ALVARADO, A. (2003). Allometric scaling and proportion regulation in the freshwater planarian Schmidtea mediterranea. Dev Dyn 226: 326-333.

OVIEDO, N.J., PEARSON, B.J., LEVIN, M. and SANCHEZ ALVARADO, A. (2008) Planarian PTEN homologs regulate stem cells and regeneration through TOR signaling. Dis Model Mech 1: 131-143.

PANENKA, W., JIJON, H., HERX, L.M., ARMSTRONG, J.N., FEIGHAN, D., WEI, T. YONG, V.W., RANSOHOFF, R.M. and MACVICAR, B.A. (2001). P2X7-like receptor 


\section{T. Sakurai et al.}

activation in astrocytes increase chemokine monocyte chemoattractant protein-1 expression via mitogen-activated protein kinase. J Neurosci 21: 7135-7142.

REDDIEN, P.W., BERMANGE, A.L., MURFITT, K.J., JENNINGS, J.R. and SANCHEZ ALVARADO, A. (2005). Identification of genes needed for regeneration, stem cell function, and tissue homeostasis by systematic gene perturbation in planaria. Dev Cell 8: 635-649.

ROBERTS, J.A., VIAL, C., DIGBY, H.R., AGBOH, K.C., WEN, H., ATTERBURYTHOMAS, A. and EVANS, R.J. (2006). Molecular properties of P2X receptors. Pflugers Arch 452: 486-500.

ROUHANA, L., SHIBATA, N., NISHIMURA, O. and AGATA, K. (2010). Different requirements for conserved post-transcriptional regulators in planarian regeneration and stem cell maintenance. Dev Biol 341: 429-443.

SABATINI, D.M. (2006). mTOR and cancer: insights into a complex relationship. Nat Rev Cancer 6: 729-734.

SHIBATA, N., ROUHANA, L. and AGATA, K. (2010). Cellular and molecular dissection of pluripotent adult somatic stem cells in planarians. Dev Growth Differ 52: 27-41.

SHIBATA, N., HAYASHI, T., FUKUMURA, R., FUJII, J., KUDOME-TAKAMATSU, T., NISHIMURA, O., SANO, S., SON, F., SUZUKI, N., ARAKI, R., ABE, M. and AGATA, K. (2012). Comprehensive gene expression analyses in pluripotent stem cells of a planarian, Dugesia japonica. Int. J. Dev. Biol. 56: 93-102.

STILES, B., GROSZER, M., WANG, S., JIAO, J. and WU, H. (2004). PTENless means more. Dev Biol 273: 175-184.
TAKEDA, H., NISHIMURA, K. and AGATA, K. (2009). Planarians maintain a constant ratio of different cell types during changes in body size by using the stem cell system. Zoolog Sci 26: 805-813.

TASAKI, J., SHIBATA, N., SAKURAI, T., AGATA, K. and UMESONO, Y. (2011). Role of c-Jun $\mathrm{N}$-terminal kinase activation in blastema formation during planarian regeneration. Dev Growth Differ 53: 389-400

UMESONO, Y., WATANABE, K. and AGATA, K. (1997). A planarian orthopedia homolog is specifically expressed in the branch region of both the mature and regenerating brain. Dev Growth Differ 39: 723-727.

WAGNER, D.E., WANG, I.E. and REDDIEN, P.W. Clonogenic neoblasts are pluripotent adult stem cells that underlie planarian regeneration. Science 332: 811-816.

WOLFF, E. and DUBOIS, F. (1948). Suy la migration des cellules de régénération chez les planaires. Rev. Suisse Zool. 55: 218-227.

YASUDA, T. and ADAMS, D.J. (2010). Physiological roles of ion channels in adult neural stem cells and their progeny. J Neurochem 114: 946-959.

YAZAWA, S., UMESONO, Y., HAYASHI, T., TARUI, H. and AGATA, K. (2009). Planarian Hedgehog/Patched establishes anterior-posterior polarity by regulating Wnt signaling. Proc Natl Acad Sci USA 106: 22329-22334.

ZHAO, Q., YANG, M., TING, A. and LOGOTHETIS, D. (2007). PIP(2) regulates the ionic current of $\mathrm{P} 2 \mathrm{X}$ receptors and $\mathrm{P} 2 \mathrm{X}(7)$ receptor-mediated cell death. Chan nels (Austin) 46-55. 


\section{Further Related Reading, published previously in the Int. J. Dev. Biol.}

Planarian regeneration: achievements and future directions after 20 years of research Emili Saló, Josep F. Abril, Teresa Adell, Francesc Cebriá, Kay Eckelt, Enrique Fernández-Taboada, Mette Handberg-Thorsager, Marta Iglesias, M Dolores Molina and Gustavo Rodríguez-Esteban

Int. J. Dev. Biol. (2009) 53: 1317-1327

Two $\mathrm{msh} / \mathrm{msx}$-related genes, Djmsh1 and Djmsh2, contribute to the early blastema growth during planarian head regeneration

Linda Mannini, Paolo Deri, Vittorio Gremigni, Leonardo Rossi, Alessandra Salvetti and Renata Batistoni

Int. J. Dev. Biol. (2008) 52: 943-952

From Planarians to Mammals - the many faces of regeneration Jerzy Moraczewski, Karolina Archacka, Edyta Brzoska, Maria-Anna Ciemerych, Iwona Grabowska, Katarzyna Janczyk-Ilach, Wladyslawa Streminska and Malgorzata Zimowska Int. J. Dev. Biol. (2008) 52: 219-227

Characterization of novel genes expressed specifically in the sexual organs of the planarian Dugesia ryukyuensis

Sumitaka Hase, Emiko Kashiwagi, Kazuya Kobayashi, Motonori Hoshi and Midori Matsumoto Int. J. Dev. Biol. (2007) 51: 345-349

Planarian pharynx regeneration revealed by the expression of myosin heavy chain-A Tomoko Sakai, Kentaro Kato, Kenji Watanabe and Hidefumi Orii

Int. J. Dev. Biol. (2002) 46: 329-332

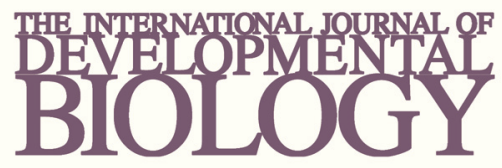

Volume 54 Nos. 6/7
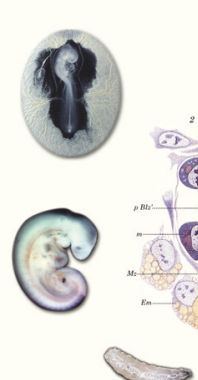

Developmental Hematopoiesis
Special Issue
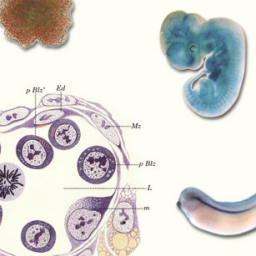

(1)

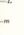

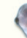
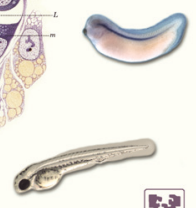

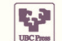

5 yr ISI Impact Factor $(2010)=2.961$

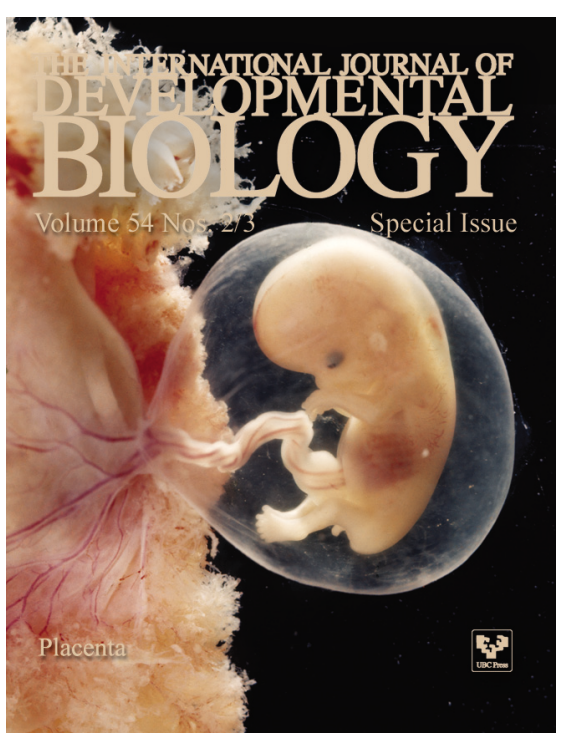

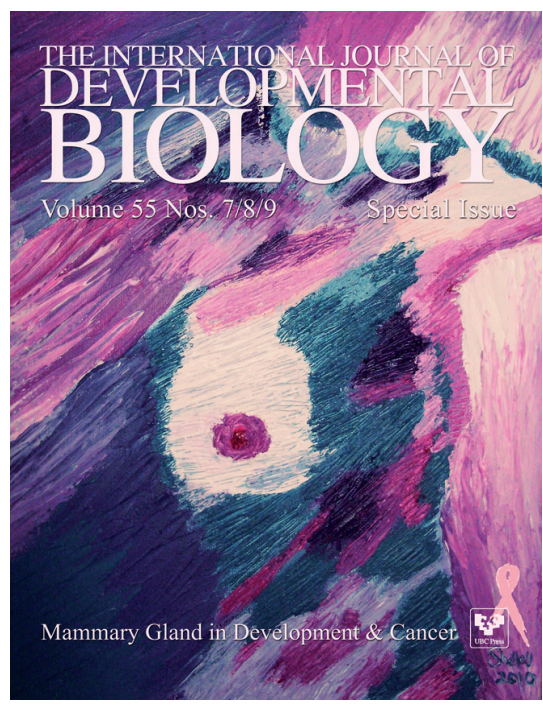

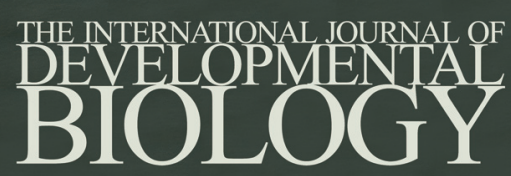

Volume 55 Nos. $4 / 5$

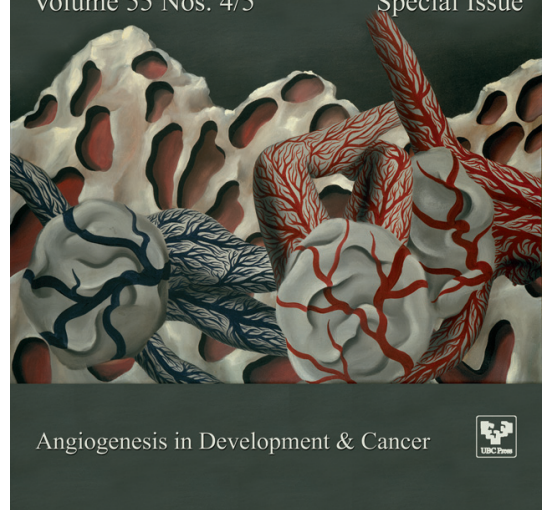

